Tropical Journal of Pharmaceutical Research June 2020; 19 (6): 1329-1337

ISSN: $1596-5996$ (print); 1596-9827 (electronic)

(C) Pharmacotherapy Group, Faculty of Pharmacy, University of Benin, Benin City, 300001 Nigeria.

Available online at http://www.tjpr.org

http://dx.doi.org/10.4314/tjpr.v19i6.30

Review Article

\title{
Leptin and systemic lupus erythematosus: A comprehensive review
}

\author{
Amal H Uzrail ${ }^{1 *}$, Lubna Swellmeen ${ }^{2}$ \\ ${ }^{1}$ Department of Medical Analysis, Faculty of Allied Medical Sciences, ${ }^{2}$ Department of Pharmaceutical Sciences, Faculty of \\ Pharmacy, Zarqa University, Zarqa, Jordan \\ *For correspondence: Email: auzrail@zu.edu.jo; Tel: 0096253821100
}

Sent for review: 21 April 2019

Revised accepted: 19 May 2020

\begin{abstract}
Leptin, a cytokine-like hormone produced by adipocytes, modulates innate and adaptive responses of the immune system. Several reports have indicated that leptin exerts pro-inflammatory effects which significantly trigger autoimmune responses in chronic inflammatory diseases e.g. systemic lupus erythematosus (SLE), an inflammatory, multi-system disease characterized by the presence of autoantibodies. Irrespective of contradictory results, many studies have indicated that leptin concentrations are increased in SLE patients. This might reflect genetic association, or a mechanism underlying the pathogenesis of SLE. To shed light on this possibility, recent studies investigated several polymorphism genes related to leptin in SLE patients from different ancestral groups. This review focuses on current understanding of the role of leptin in the pathogenesis of SLE and its immunomodulatory effects. This is expected to provide new leptin-based therapeutic interventions as modern approaches which are safer than the currently used ones for the treatment of SLE.
\end{abstract}

Keywords: Leptin, Systemic Lupus Erythematosus, Polymorphism, Gene expression

\begin{abstract}
This is an Open Access article that uses a fund-ing model which does not charge readers or their institutions for access and distributed under the terms of the Creative Commons Attribution License (http://creativecommons.org/licenses/by/4.0) and the Budapest Open Access Initiative (http://www.budapestopenaccessinitiative.org/read), which permit unrestricted use, distribution, and reproduction in any medium, provided the original work is properly credited.
\end{abstract}

Tropical Journal of Pharmaceutical Research is indexed by Science Citation Index (SciSearch), Scopus, International Pharmaceutical Abstract, Chemical Abstracts, Embase, Index Copernicus, EBSCO, African Index Medicus, JournalSeek, Journal Citation Reports/Science Edition, Directory of Open Access Journals (DOAJ), African Journal Online, Bioline International, Open-J-Gate and Pharmacy Abstracts

\section{INTRODUCTION}

Adipose tissue possesses endocrine and immune properties. It produces various cytokines such as IL- 6 and TNF- $\alpha$, as well as the adipokines leptin, adiponectin and resistin. These cytokines regulate a variety of physiological processes such as food intake, insulin sensitivity, atherosclerosis, immunity and inflammation [1]. Systemic lupus erythematosus (SLE) is an autoimmune disease (type III hypersensitivity reaction) due to the accumulation of immune complexes in different organs, resulting in multisystem damage and various clinical manifestations arising from loss of immunological tolerance and the presence of auto-antigens [2]. The etiopathogenesis of SLE is facilitated by environmental factors and sex hormones (especially estrogen) which might trigger abnormal autoimmune responses in genetically predisposed individuals [3]. Moreover, the severity and clinical manifestations of SLE are linked to altered production of multiple cytokines [2]. Leptin is a cytokine-like hormone with proinflammatory properties. Increasing evidence show that low and high levels of leptin play are involved in the pathogenesis of various autoimmune diseases [4]. Therefore, leptin has 
been studied as a target of new therapeutic approaches for autoimmune diseases [5].

\section{LEPTIN AND SIGNAL TRANSDUCTION PATHWAYS}

Leptin is a non-glycosylated peptide hormone (16-KD) encoded by the obese gene synthesized mainly in the adipose tissue, especially in differentiated mature adipocytes. It is also secreted in small amounts by the gastric mucosa, skeletal muscle, placenta and mammary epithelium [6]. Leptin is known as a satiety factor with multiple effects such as regulation of endocrine function, reproduction and immunity [7].

The three-dimensional structure of leptin is highly similar to that of members of the long-chain helical cytokines, for example interleukin-6 (IL-6). There are six different isoforms of leptin receptor (OB-R) due to alternating splicing of OB-RmRNA [8]. The only isoform with signaling capabilities like IL-6 cytokine receptors is Ob-Rb. This isoform is expressed in the hypothalamus and cardiovascular system, and also in different types of immune cells. It is thought that the ubiquitous expression of $\mathrm{Ob}-\mathrm{Rb}$ receptor might reflect the pleiotropic effect of leptin [9].

Upon binding to its receptor (OB-Rb), leptin activates Janus-family tyrosine kinase 2 (JAK2) signaling pathway by auto-phosphorylating specific tyrosine residues in the cytoplasmic domain. This leads to activation of SH2containing tyrosine-specific protein phosphatase (SHP2) and signal transducer and activator of transcription 3 (STAT3). Then, STAT3 activates gene transcription of the suppressor of cytokine signaling 3 (SOCS3), which negatively regulates leptin signaling, and other target genes. In addition, leptin activates extracellular signalregulated kinase (ERK)/MAPK pathway (RasRaf-MEK-ERK signaling cascade). Leptin also mediates in the activation of phosphatidylinositol3-kinase (PI3K)/Akt via the insulin receptor substrate 1/2 (IRS1/2) and protein tyrosine phosphatase 1B (PTP1B), which also acts as a negative regulator of leptin signaling (Figure 1) [7].

\section{LEPTIN AND IMMUNITY}

Early studies of thymus atrophy in $(d b / d b)$ mice revealed the regulatory role of leptin on the function of immune cells. Later studies confirmed that leptin is involved in modulating responses in innate immunity and adaptive immunity [8]. In innate immunity, leptin increases CD11b marker expression on the surface of leukocytes,

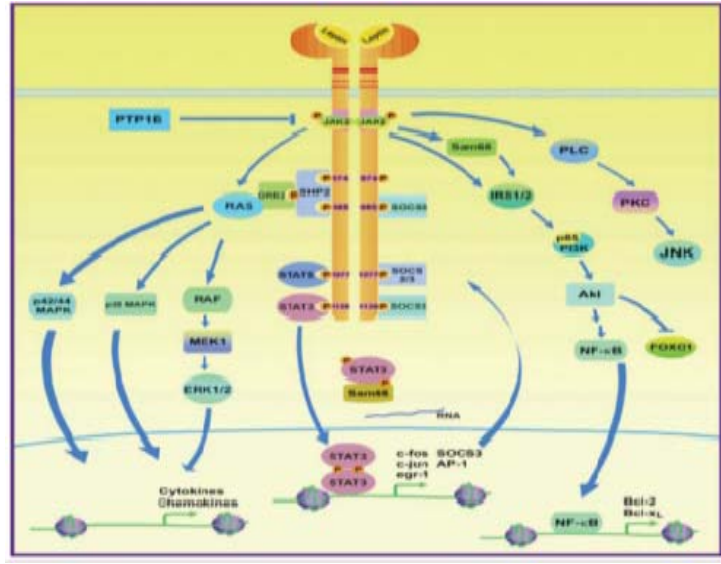

Figure 1: Signaling pathways of leptin (adapted from Zhou et al., 2013)

activates neutrophils by upgrading chemotaxis, and also activates natural killer (NK) cells, thereby increasing their cytotoxic capabilities. Moreover, leptin enhances the secretion of interleukin-2 (IL-2) via the activation of STAT3. Leptin also stimulates the proliferation of monocytes and macrophages, and increases their phagocytic effects and the release of proinflammatory cytokines [10].

With respect to its effect on adaptive immunity, leptin maintains thymic homeostasis by exerting anti-apoptotic influence on mature $T$ cells and the precursors of hematopoiesis [11]. It also activates the proliferation of naïve $T$ cells and secretion of IL-2 through the activation of MAPK and PI3K pathways [12]. Leptin enhances a shift in immune responses in the direction of $\mathrm{T}$ helper 1 (Th1)-cells by increasing the release of interferon- $\gamma$ (IFN- $\gamma$ ) and TNF- $\alpha$ [13]. Leptin tends to suppress the proliferation of regulatory T-cells (Treg) $\mathrm{CD} 4^{+} \mathrm{CD} 25^{+}$which are potent suppressors of autoimmunity $[11,14]$. Therefore, reduction in leptin concentrations leads to a decrease in proliferation of effector $\mathrm{T}$ cells, increased population of Treg cells, and downregulation of Th1 immunity [10].

\section{ROLE OF LEPTIN IN PATHOGENESIS OF SLE}

Systemic lupus erythematosus (SLE) is characterized by sex bias: females are predominantly more affected than males. This phenomenon is associated with differences in gene expression and sex hormones between the two sexes [15]. In healthy individuals, women have 5-10 times higher levels of leptin than men [16]. The increase in leptin concentration during inflammation points to its pro-inflammatory properties which might be responsible for systemic inflammation in SLE [17]. Indeed, circulating leptin levels are abnormally increased 
in SLE [18]. Hyperleptinemia, which is associated with a direct increase in the number of Th17 cells, and decreases in the number of Treg cells, are considered as underlying factors in the development of SLE [19]. Studies have found that leptin stimulated proliferation of autoreactive T-cells in lupus-prone mice, thereby promoting autoimmunity [18].

Current advances in research on SLE have shown that the cytokine-like function of leptin may account for the molecular mechanism underlying the pathophysiology of SLE, and also revealed the possibility of using leptin as a predictor of severity of SLE, and serologic marker in identification of patients at risk of developing the active phase of the disease [20]. It is very likely that understanding how leptin modulates autoimmune responses in SLE might provide new possibilities for development of leptin-targeted therapies [21].

Amarilyo and coworkers have reported that abnormally high level of leptin in SLE triggers Tcell survival by increasing bcl-2 expression which modulates apoptosis in T-cells. Leptin also activates the proliferation of autoreactive T-cells in lupus-prone mice (NZBXNZW) F1 which carry an autoreactive T-cell repertoire. In addition, leptin may stimulate phagocytosis of apoptotic cells by macrophages in (NZBXNZW) F1 through modulating cAMP levels in macrophages [22]. This finding was linked to increased levels of apoptosis-derived antigens which favor the proliferation and responses of reactive $\mathrm{T}$ cell to the antigens. The authors suggested that that the inhibition of this process by blocking leptin may be of therapeutic application for SLE, since it may modulate SLE-associated autoimmune responses [22].

A more recent study by Lourenço and colleagues has shown that genetically-induced deficiency of leptin in mice protected the animals from developing SLE, and decreased the production of autoantibodies, specifically anti-dsDNA antibodies, and renal diseases [21]. Anti-dsDNA antibodies are produced mainly during the active phase of SLE and are associated with lupus nephritis [22]. These autoantibodies were leptindependent, since leptin blockade protected the mice model of lupus from developing autoantibodies, while administration of leptin promoted development of the active phase of disease. This finding suggests that leptin could possibly be exploited as new therapeutic intervention for SLE [23].

\section{PLASMA or SERUM LEPTIN AND SLE}

Despite availability of several studies on circulating levels of leptin in SLE patients, there are contradictory results on the association between plasma or serum leptin levels and SLE (Table 1). Many researchers reported elevated leptin in SLE patients, but failed to reach a clear conclusion on whether these increased levels were as a result of the disease, or were responsible for the pathogenesis of the disease. The results varied in patients according to demographic data, weight or dietary components, and disease markers such as antidsDNA antibodies [24]. For example, Lourenco and colleagues reported that leptin promoted the development of different types of autoantibodies, specifically anti-dsDNA antibodies [21], while another study found no association between antidsDNA antibodies and serum leptin levels [25]. In addition, there were variations in clinical manifestations, laboratory results and disease severity, with respect to leptin levels in SLE patients in the different studies. However, many of these studies failed to correlate the leptin levels with severity of SLE [24].

In order to provide a clearer picture of the relationship between plasma/serum levels of leptin and SLE, a study was conducted by Li and coworkers [24], in which eleven studies [20,25$33,35]$ were pooled through a meta-analysis. The study showed no significant difference in levels of leptin in plasma or serum between the whole groups of SLE patients and controls. However, analysis of leptin concentrations between subgroups of SLE patients revealed that plasma or serum leptin levels were significantly elevated in Asian SLE patients aged $\geq 40$ years whose BMI values were < 25. Thus, the authors suggested that age, $\mathrm{BMI}$, region and race might be associated with leptin levels in SLE patients, taking in consideration the effect of other factors such as clinical data, gender and environmental factors.

More recently, Badaway and colleagues [36] studied tumor necrosis factor (TNF)-like weak inducer of apoptosis (TWEAK) and leptin concentrations in the sera of 90 SLE patients with anti-phospholipid syndrome (APS). The patients were divided into four groups: group $A$ (30 SLE patients), group B (26 SLE patients with secondary APS i.e. SLE-APS), group C (14 SLE patients with primary APS i.e. pAPS), and group $D$ control $(n=20)$. The authors reported significant increases in serum leptin and TWEAK in pAPS patients, when compared to other patients and control. 
Table 1: Summary of studies on serum/plasma leptin levels in SLE patients

\begin{tabular}{|c|c|c|c|c|c|c|c|c|c|}
\hline Year & Reference & $\begin{array}{l}\text { Study } \\
\text { type }\end{array}$ & $\begin{array}{l}\text { Patients } \\
\text { (n) }\end{array}$ & $\begin{array}{l}\text { Controls } \\
\text { (n) }\end{array}$ & $\begin{array}{l}\text { Leptin } \\
\text { concentration }\end{array}$ & $P$-value & $\begin{array}{l}\text { Disease } \\
\text { severity }\end{array}$ & Region & Observation \\
\hline 2014 & $\begin{array}{l}\text { Barbosa et al } \\
\text { [25] }\end{array}$ & $\begin{array}{l}\text { Case- } \\
\text { control }\end{array}$ & 52 & 33 & $\begin{array}{l}\text { Increased } \\
\text { (serum) }\end{array}$ & $<0.001$ & $\begin{array}{l}\text { No } \\
\text { correlation }\end{array}$ & Brazil & $\begin{array}{l}\text { High leptin levels associated with renal } \\
\text { diseases, while low levels associated with } \\
\text { lupus anticoagulant and anticardiolipin }\end{array}$ \\
\hline 2014 & $\begin{array}{l}\text { Afroze et al } \\
{[26]}\end{array}$ & $\begin{array}{l}\text { Case- } \\
\text { control }\end{array}$ & 100 & 100 & $\begin{array}{l}\text { Increased } \\
\text { (serum) }\end{array}$ & $<0.001$ & Not done & India & \\
\hline 2011 & $\begin{array}{l}\text { Vadacca et al } \\
{[27]}\end{array}$ & $\begin{array}{l}\text { Case- } \\
\text { control }\end{array}$ & 60 & 29 & $\begin{array}{l}\text { Increased } \\
\text { (serum) }\end{array}$ & 0.035 & Correlation & Italy & \\
\hline 2011 & $\begin{array}{l}\text { Mcmahon et al } \\
{[20]}\end{array}$ & $\begin{array}{l}\text { Case- } \\
\text { control }\end{array}$ & 250 & 122 & $\begin{array}{l}\text { Increased } \\
\text { (plasma) }\end{array}$ & $<0.001$ & NA & America & $\begin{array}{l}\text { Serum leptin levels were associated with } \\
\text { increased risk of atherosclerosis }\end{array}$ \\
\hline 2010 & Kim et al [28] & $\begin{array}{l}\text { Case- } \\
\text { control }\end{array}$ & 70 & 39 & $\begin{array}{l}\text { Decreased } \\
\text { (serum) }\end{array}$ & $<0.05$ & NA & Korea & $\begin{array}{l}\text { High leptin concentrations were associated } \\
\text { non significantly with malar rash, oral ulcers, } \\
\text { alopecia, arthritis and renal disorders in SLE } \\
\text { patients. }\end{array}$ \\
\hline 2009 & $\begin{array}{l}\text { De Sanctis et } \\
\text { al [29] }\end{array}$ & $\begin{array}{l}\text { Case- } \\
\text { control }\end{array}$ & 60 & 60 & $\begin{array}{l}\text { Decreased } \\
\text { (serum) }\end{array}$ & $<0.005$ & NA & Venezuela & \\
\hline 2009 & $\begin{array}{l}\text { Chung et al } \\
{[30]}\end{array}$ & $\begin{array}{l}\text { Case- } \\
\text { control }\end{array}$ & 109 & 78 & $\begin{array}{l}\text { Increased } \\
\text { (serum) }\end{array}$ & $<0.001$ & $\begin{array}{l}\text { No } \\
\text { correlation }\end{array}$ & America & $\begin{array}{l}\text { There was a correlation between leptin levels } \\
\text { and insulin resistance (IR) in SLE patients }\end{array}$ \\
\hline 2009 & Al et al (31) & $\begin{array}{l}\text { Cohort } \\
\text { study }\end{array}$ & 105 & 77 & $\begin{array}{l}\text { Increased } \\
\text { (serum) }\end{array}$ & $<0.05$ & $\begin{array}{l}\text { No } \\
\text { correlation }\end{array}$ & Canada & \\
\hline 2008 & $\begin{array}{l}\text { Wislowska et al } \\
\text { [32] }\end{array}$ & $\begin{array}{l}\text { Case- } \\
\text { control }\end{array}$ & 30 & 30 & $\begin{array}{l}\text { No difference } \\
\text { (serum) }\end{array}$ & $>0.05$ & $\begin{array}{l}\text { No } \\
\text { correlation }\end{array}$ & Poland & $\begin{array}{l}\text { Low leptin levels associated with arthritis and } \\
\text { CNS }\end{array}$ \\
\hline 2007 & $\begin{array}{l}\text { Elwakkad et al } \\
\text { [33] }\end{array}$ & $\begin{array}{l}\text { Case- } \\
\text { control }\end{array}$ & 12 & 21 & $\begin{array}{l}\text { Increased } \\
\text { (serum) }\end{array}$ & $<0.05$ & $\begin{array}{l}\text { No } \\
\text { correlation }\end{array}$ & Egypt & \\
\hline 2006 & Sada et al [34] & $\begin{array}{l}\text { Case- } \\
\text { control }\end{array}$ & 37 & 80 & $\begin{array}{l}\text { Plasma } \\
\text { (increased) }\end{array}$ & $<0.01$ & NA & Japan & $\begin{array}{l}\text { The percentages of hypertension and DM } \\
\text { higher in SLE patients than controls, } 32 \% \text { of } \\
\text { SLE patients with IR showed higher } \\
\text { incidence of hypertension and proteinuria } \\
\text { than those without, Increased adiponectin in } \\
\text { SLE patients, but inversely correlated with IR }\end{array}$ \\
\hline 2002 & $\begin{array}{l}\text { Garcia- } \\
\text { Gonzalez et al } \\
350\end{array}$ & $\begin{array}{l}\text { Cross- } \\
\text { sectional } \\
\text { study }\end{array}$ & 41 & 23 & $\begin{array}{l}\text { Increased } \\
\text { (serum) }\end{array}$ & 0.023 & $\begin{array}{l}\text { No } \\
\text { correlation }\end{array}$ & Mexico & \\
\hline
\end{tabular}

NA: Not assessed; DM: diabetes mellitus, IR: insulin resistance 
The study investigated the feasibility of using these analyzed parameters as biomarkers for prediction of atherosclerosis. The results showed no significant correlation between TWEAK or leptin, and SLE. However, serum levels of leptin and TWEAK were significantly increased in pAPS patients, when compared to other patients and controls. They also found that cholesterol and triglyceride levels were significantly increased in SLE patients and pAPS group, relative to control, while HDL was markedly decreased in SLE, when compared to SLE-APS patients.

Diaz-Rizo and coworkers [37] investigated serum levels of leptin in 103 SLE women in relation to kidney damage, in a study involving 30 SLE patients who suffered from lupus nephritis (LN) and 73 SLE patients without LN. The study showed no difference in serum leptin levels between LN group and those without LN. On the other hand, there was a non-significant trend towards higher levels of serum leptin in SLE patients, but these levels were not related to the presence or severity of proteinuria.

In another study conducted by Mohammed and colleagues [38], leptin concentrations in sera collected from 40 SLE patients were correlated with laboratory results for CBC, ESR, ANA, antidsDNA, C3 and C4, as well as liver and kidney functions tests, and SLEDAl index. The study showed that serum leptin levels were significantly higher in SLE patients than in controls. In addition, the levels of these parameters were significantly associated with $\mathrm{BMI}$ and total cholesterol, but non-significantly with SLEDAI index and clinical features of SLE (malar rash, fever, and neuropsychiatric symptoms).

\section{ASSOCIATION BETWEEN LEPTIN-RELATED POLYMORPHISMS AND SLE}

Genetics play a key role in the pathogenesis of SLE, since many candidate genes tested in genetic association studies have been implicated in the pathogenesis of SLE [39]. However, only few gene association studies have focused on the association between leptin-related polymorphisms and SLE [40]. Afroze and colleagues [26] determined LEPR gene polymorphism (LEPR Q223R), a polymorphism in leptin gene $(A>G$ transition) in 100 Kashmiri SLE patients. The $A>G$ transition might alter signal transduction by impairing the binding of leptin to its receptor, thereby impairing $L E P R$ expression. The study showed that $L E P R$ gene polymorphism was associated with increased susceptibility to SLE in the Kashmiri population. In the study, carriers of variant genotype (A/G+
$\mathrm{G} / \mathrm{G}$ ) or the rare $\mathrm{G}$ allele were susceptible to developing SLE. However, there was a limitation in the study, in that it did not reach a conclusion on the association between Q223R polymorphism and SLE due to small size of the study sample of SLE patients with homogenous ethnicity.

Therefore, another study conducted by Zhao and coworkers [41] analyzed a larger number of SLE patients from multiple ancestral groups. The authors tested several single nucleotide polymorphisms (SNPs) within several leptinrelated genes i.e. leptin gene $(L E P)$, leptin receptor $(L E P R)$, peroxisome proliferatoractivated receptor (PPAR)- $V$ (PPARG), and growth hormone secretagogue receptor (GHSR).The SNPs were selected based on their relationship with the leptin gene and its receptor, and other genes association with the regulation of expression of leptin gene. Genetic variants of $L E P$ may regulate the expression, function and catabolism of leptin. For $L E P R$, polymorphisms of all isomers were assessed since they may influence the catabolism of leptin, or induce sustained effect of leptin [42]. Polymorphisms of PPARG were analyzed because leptin downregulated PPAR- $y$ expression, leading to increased levels of pro-inflammatory cytokines (IL-1 $\beta$, IL-6 and TNF- $\alpha$ ) release [43]; while polymorphisms of GHSR exerted the opposite effects on leptin by inhibiting the release of these pro-inflammatory cytokines [44].

Zhao and colleagues performed the study by genotyping DNA samples collected from 13,706 participants $(8,269$ SLE patients and 7,437 controls) from four different ethnic groups to investigate the involvement of leptin pathwayrelated gene polymorphisms in the pathogenesis of SLE. Four ethnic groups were enrolled in the study: European Americans (3,966 SLE patients and 3,543 controls); African Americans (1,527 SLE patients and 1,812 controls); East Asians (1,272 SLE patients and 1,270 controls), and Hispanics (1,504 cases and 812 controls). The study used haplotype tag SNPs for genotyping the chosen genes, resulting in genotyping of 32 SNPS: 7 SNPS for LEP, 10 SNPs for LEPR, 3 SNPs for GHSR, and 12 SNPs for PPARG. These SNPS were subsequently passed through genetic association test. The study found an association between the A allele of rs12706832 in $L E P$ and low susceptibility to SLE in African Americans, while the A allele of rs3828942 was linked to increased risk for SLE in the same group. For LEPR, the C allele of rs6690625 and the A allele of rs1892535 showed association with low susceptibility to SLE in Hispanics. 
In GHSR, the G allele of rs2948694 showed an association with decreased risk of SLE in European Americans. For PPARG, the A allele of rs12633551 and A allele of rs3856806 were associated with low risk of SLE in European Americans. Although these data showed significant association signals at several loci, the associations did not remain significant after correction for multiple testing. Therefore, the study failed to confirm associations between any of the defined leptin-associated polymorphisms and increased susceptibility to SLE.

$\mathrm{Li}$ and his team [45] investigated the association between SNPs of $L E P$ and $L E P R$ with increased risk of SLE in a cohort of Chinese population. They genotyped four SNPs of LEP and nine SNPs of LEPR genes with improved multiple ligase detection reaction (iMLDR).

The study showed no significant differences between SLE patients and controls in the distribution of frequencies of alleles and genotypes of all tested SNPs. In addition, the effects of genotypes for the recessive, dominant and additive models showed no significant association with SLE. Subsequent analysis showed that the frequencies of TT genotype and $\mathrm{T}$ allele of the LEP rs2071045 polymorphisms were significantly increased in patients with pericarditis, while frequencies of genotype GA/AA and $A$ allele of the rs1137100 polymorphism in $L E P R$ were both linked to photosensitivity in SLE patients, in accordance with the distribution of genotype and allele of rs3806318 polymorphism. The study also showed no significant differences in serum leptin concentrations amongst SLE patients of different genotypes.

\section{LEPTIN GENE EXPRESSION}

There are increasing evidence of the involvement of leptin in maintenance of the immune system [46]. Leptin may stimulate activation and proliferation of peripheral blood mononuclear cells (PBMCs) through its receptors which are expressed on these cells. Leptin activates the JAK-STAT, IRS-1-PI3K and MAPK signaling pathways, and stimulates phosphorylation of tyrosine residues of the RNA-binding protein known as sterile motif (SAM), thereby modulating RNA metabolism [47]. Several factors might participate in regulating the expression of leptin gene, especially food intake and hormones such as insulin and sex hormones [48]. For example, it has been found that during feeding, insulin activates leptin secretion, while during starvation, a fall in insulin levels leads to a decrease in leptin release [49].The expression of leptin gene is also increased by ovarian sex steroids, but it is inhibited by testosterone [50]. In addition, leptin release is increased during acute infection, sepsis, and inflammation due to the release of inflammatory mediators such as IL-1, TNF- $\alpha$ and LIF [51].

Several in vitro studies have been conducted on the immunomodulatory effect of leptin using PBMCs $[52,53]$. These studies might provide an insight into leptin-targeted therapeutic interventions for SLE treatment, instead of the traditional treatment strategies. Brink and colleagues [52] have reported that exposure of PBMCs to leptin induced sustained phosphorylations of p38 MAP kinase and ribosomal protein $\mathrm{S} 6$ involved in initiation of mRNA translation. This finding may account for the molecular mechanisms underlying the observed immunomodulatory effect of leptin in PBMCs. Another study conducted by ZarkeshEsfahani et al showed that leptin administration directly induced inflammatory responses and expression of its receptors in PBMCs [54].

Dixit and coworkers [55] showed that leptin induced the production of growth hormone by PBMCs by activating protein kinase $C$ (PKC) and nitric oxide-dependent pathways. This effect might play an important role in immune homeostasis, thereby indicating the cytokine-like effect of this hormone on immune responses through regulation of the survival and proliferation of immune cells.

More recently, leptin gene expression was determined for the first time using PBMCs from healthy subjects [53]. However, there are no extant studies on the expression levels of leptin in SLE patients. This could be applied for development of new therapies for SLE based on leptin targeting. These therapies will be safer than the currently used methods which are toxic or cause adverse side effects in SLE patients.

\section{CONCLUSION AND FUTURE PERSPECTIVES}

Recent understanding of the role of leptin in immune responses and development of SLE, an autoimmune disease, provide a possibility for new leptin-targeted therapies that decrease leptin concentrations by repressing the expression of the leptin gene. These therapies are considered much safer than traditional treatment methods which produce adverse and toxic effects in SLE patients. This implies different therapeutic approaches for SLE, and use of leptin agonists which are effective in repressing enhanced T-cell immunity as a component of autoimmunity. Another therapeutic 
possibility is to use drugs that reduce circulating levels of leptin, for example, drugs that activate peroxisome proliferator-activated receptor $\mathrm{Y}$ which functions as transcription factor when activated by its endogenous ligand (15-deoxy$\Delta^{12,14_{-}} \quad$ prostaglandin- $J_{2}$ ), resulting in the repression of the expression of obese gene [56].

\section{DECLARATIONS}

\section{Acknowledgement}

This research was supported by Faculties of Allied Medical Health Sciences and Pharmacy, Zarqa University.

\section{Conflict of interest}

No conflict of interest is associated with this work.

\section{Contribution of authors}

We declare that this work was done by the authors named in this article and all liabilities pertaining to claims relating to the content of this article will be borne by the authors.

\section{Open Access}

This is an Open Access article that uses a funding model which does not charge readers or their institutions for access and distributed under the terms of the Creative Commons Attribution License (http://creativecommons.org/licenses/by/ 4.0) and the Budapest Open Access Initiative (http://www.budapestopenaccessinitiative.org/rea d), which permit unrestricted use, distribution, and reproduction in any medium, provided the original work is properly credited.

\section{REFERENCES}

1. Antuna-Puente B, Feve B, Fellahi $S$, Bastard JP. Adipokines: the missing link between insulin resistance and obesity. Diabetes Metab 2008; 34: 2-11.

2. Rahman A, Isenberg DA. Systemic lupus erythematosus. N Engl J Med 2008; 358: 929-939.

3. Matarese G, Leiter EH, La Cava A. Leptin in autoimmunity: many questions, some answers. Tissue antigens 2007; 70(2): 87- 95.

4. Tsokos GC. Systemic lupus erythematosus. N Engl J Med 2011; 365(22): 2110-2121.

5. Cojocaru M, Cojocaru IM, Siloşi I, Rogoz S. Role of leptin in autoimmune diseases. Maedica 2013; 8(1): 68-74.

6. deRosa V, Procaccini C, Cali G, Pirozzi G, Fontana S, Zappacosta S, La Cava A, Matarese G. A key role of leptin in the control of regulatory $T$ cell proliferation. Immunity 2007; 26(2): 241-255.

7. Zhou Y, Rui L. Leptin signaling and leptin resistance. Front Med 2013; 7(2): 207-222.

8. Stofkova A. Leptin and adiponectin: from energy and metabolic dysbalance to inflammation and autoimmunity. Endocr Regul 2009; 43: 157-168.

9. Fernandez-Riejos $P$, Najib S, Santos-Alvarez J, MartínRomero C, Pérez-Pérez A, González-Yanes C, Sánchez-Margalet $V$. Role of leptin in the activation of immune cells. Mediators Inflamm 2010; 2010: 568343.

10. Lam QL, Lu L. Role of leptin in immunity. Cell mol Immunol 2007; 4(1): 1-13.

11. Papathanassoglou E, El-Haschimi K, Li XC, Matarese G, Strom T, Mantzoros C. Leptin receptor expression and signaling in lymphocytes: kinetics during lymphocyte activation, role in lymphocyte survival, and response to high fat diet in mice. J Immunol 2006; 176(12): 77457752.

12. Lord GM, Matarese G, Howard JK, Bloom SR, Lechler RI. Leptin inhibits the anti-CD3-driven proliferation of peripheral blood $T$ cells but enhances the production of Proinflammatory cytokines. J Leukoc Biol 2002; 72(2): 330-338.

13. Matarese G, Carrieri PB, La Cava A, Perna F, Sanna V, De Rosa V, Aufiero D, Fontana S, Zappacosta S. Leptin increase in multiple sclerosis associates with reduced number of $C D 4+C D 25+$ regulatory $T$ cells. Proc Natl Acad Sci (USA) 2005; 102(14): 5150-5155.

14. Otero $M$, Lago $R$, Lago F, Casanueva FF, Dieguez $C$, Gómez-Reino JJ, Gualillo $O$. Leptin, from fat to inflammation: old questions and new insights. FEBS Lett 2005; 579(2): 295-301.

15. Zandman-Goddrd G, Peeva E, Shoenfeld Y. Gender and autoimmunity. Autoimmun Rev 2007; 6: 366-372.

16. La cava $A$, Matarese $G$. The weight of leptin in immunity. Nat Rev Immunol 2004; 4: 371-379.

17. Versini $M$, Jeandel PY, Rosenthal $E$, Shoenfeld $Y$. Obesity in autoimmune diseases: not a passive bystander. Autoimmun Rev 2014; 13(9): 981-1000.

18. Amarilyo G, Likuni N, Shi F. Leptin promotes lupus T-cell autoimmunity. Clin Immunol 2013; 149: 530-553.

19. Fujita Y, Fujii T, Mimori T, Sato T, Nakamura T, Iwao $H$, Nakajima A, Miki M, Sakai T, Kawanami $T$, et al. Deficient leptin signaling ameliorates systemic lupus erythematosus lesions in MRL/Mp-Fas/pr mice. J Immunol 2014; 192(3): 979-984.

20. McMahon M, Skaggs BJ, Sahakian L, Grossman J, FitzGerald J, Ragavendra N, Charles-Schoeman C, Chernishof M, Gorn A, Witztum JL, et al. High plasma leptin levels confer increased risk of atherosclerosis in women with systemic lupus erythematosus. Ann Rheum Dis 2011; 70(9): 1619-1624.

21. Lourenço EV, Liu A, Matarese G. Leptin promotes systemic lupus erythematosus by increasing autoantibody production and inhibiting immune regulation. PNAS 2016; 113(38): 10637-10642. 
22. Amarilyo G, Likuni N, Liu A, Matarese G, La Cava A. Leptin enhances availability of apoptotic cell-derived self-antigen in systemic lupus erythematosus. PLOS One 2014; 9(11): e112826.

23. Quismorio FD, Torralba KD. Clinical applications of serologic tests, serum protein abnormalities, and other clinical laboratory tests in SLE. Dubois' Lupus Erythematosus and Related Syndromes, eds Wallace DJ, Hahn BH (Saunders Elsevier, Philadelphia), 8th Ed, 2013; pp 526-540.

24. Li HM, Zhang TP, Leng RX, Li XP, LI XM, Pan HF. Plasma/serum leptin levels in patients with systemic lupus erythematosus: a meta-analysis. Arch Med Res 2015; 46(7): 551-556.

25. Barbosa VdeS, Francescantonio PL, Silva NA. Leptin and adiponectin in patients with systemic lupus erythematosus: clinical and laboratory correlations. Rev Bras Reumatol 2015; 55(2): 140-145.

26. Afroze D, Yousuf A, Ali R, Kawoosa F, Akhtar T, ReshiS, Shah ZA. Serum leptin levels, leptin receptor gene (LEPR) polymorphism, and the risk of systemic lupus erythematosus in Kashmiri population. Immunol Invest 2015; 44(2): 113-125.

27. Vadacca $M$, Margiotta $D$, Rigon A, Cacciapaglia $F$, Coppolino G, Amoroso A, Afeltra A. Adipokines and systemic lupus erythematosus: relationship with metabolic syndrome and cardiovascular disease risk factors. J Rheumatol 2009; 36(2): 295-297.

28. Kim HA, Choi GS, Jeon JY, Yoon JM, Sung JM, Suh CH. Leptin and ghrelin in Korean systemic lupus erythematosus. Lupus 2010; 19(2): 170-174.

29. De Sanctis JB, Zabaleta M, Bianco NE, Garmendia JV, Rivas L. Serum adipokine Levels in patients with systemic lupus erythematosus. Autoimmunity 2009; 42(4): 272-274.

30. Chung CP, Long AG, Solus JF, Rho YH, Oeser A, Raggi $P$, Stein CM. Adipocytokines in systemic lupus erythematosus: relationship to inflammation, insulin resistance and coronary atherosclerosis. Lupus 2009; 18(9): 799-806.

31. Al M, Ng L, Tyrrell P, Bargman J, Bradley T, Silverman E. Adipokines as novel biomarkers in paediatric systemic lupus erythematosus. Rheumatol (Oxford, England) 2009; 48(5): 497-501.

32. Wislowska M, Rok M, Stepien K, Kuklo-Kowalska A. Serum leptin in systemic lupus erythematosus. Rheumatol Int 2008; 28(5): 467-473.

33. Elwakkad AS, Said RN, Muhammad SI, Saleh MT, Elhamshary A. Role for leptin and prolactin in human juvenile rheumatic diseases. Pak J Biol Sci 2007; 10(12): 1984-1989.

34. Sada KE, Yamasaki Y, Maruyama M, Maeshima Y, Makino H. Altered levels of adipocytokines in association with insulin resistance in patients with SLE. J Rheumatol 2006; 33(8): 1545-1552.

35. Garcia-Gonzalez A, Gonzalez-Lopez L, Valera-Gonzalez IC, Cardona-Muñoz EG, Salazar-Paramo M, GonzálezOrtiz M, Martínez-Abundis E, Gamez-Nava J. Serum leptin levels in women with systemic lupus erythematosus, Rheumatol Int 2002; 22(4): 138-141.

36. Badawy A, Abd El-Hamid A, Mohamed N, Darwish E, Wassef $M$, Elfirgani $H$. Serum tumour necrosis factor (TNF)-like weak inducer of apoptosis (TWEAK) and leptin as biomarkers of accelerated atherosclerosis in patients with systemic lupus erythematosus and antiphospholipid syndrome. Egypt Rheumatol 2017; 39(1): 7-12.

37. Diaz-Rizo V, Bonilla-Lara D, Gonzalez-Lopez L, Sanchez-Mosco D, Fajardo-Robledo NS, PerezGuerrero EE, Rodriguez-Jimenez NA, Saldaña-Cruz $A M$, Vazquez-Villegas ML, Gomez-Bañuelos E, et al. Serum levels of adiponectin and leptin as biomarkers of proteinuria in lupus nephritis. PLoS One 2017; 12(9): e0184056.

38. Mohammed SF, Abdalla MA, Ismail WM, Sheta MM. Serum leptin in systemic lupus erythematosus patients: Its correlation with disease activity and some disease parameters. Egypt Rheumatol 2018; 40(1): 23-27.

39. Bentham J, Vyse TJ. The development of genome-wide association studies and their application to complex diseases, including lupus. Lupus 2013; 22 (12): 12051213.

40. La Cava A. Leptin-related polymorphisms and SLE. Inflamm Cell signal 2016;3: e1171.

41. Zhao J, Wu H, Langefeld CD, Kaufman KM, Kelly JA, Bae SC, Alarcón-Riquelme ME, Alarcón GS, Anaya JM, Criswell LA, et al. Genetic associations of leptin-related polymorphisms with systemic lupus erythematosus. Clin Immunol 2015; 161(2): 157-162.

42. Onions KL, Hunt SC, Rutkowski MP, Klanke CA, Su YR, Reif M, Menon AG. Genetic Markers at the Leptin (OB) Locus are Not Significantly Linked to Hypertension in African Americans. Hypertension 1998; 31: 1230-1234.

43. Cabrero A, Cubero $M$, Llaverías $G$, Alegret $M$, Sánchez $R$, Laguna JC, Vázquez-Carrera M. Leptin downregulates peroxisome proliferator-activated receptor $Y$ (PPAR-y) mRNA levels in primary human monocytederived macrophages. Mol Cell Biochem 2005; 275(12): 173-179.

44. Liu ZZ, Wang WG, Li Q, Tang M, Li J, Wu W-t, Wan Y-h, Wang Z-g, Bao S-s, Fei J. Growth hormone secretagogue receptor is important in the development of experimental colitis. Cell Biosci 2015; 5: 12.

45. Delgado-Vega A, Sánchez E, Löfgren S, Castillejo-López C, Alarcón-Riquelme ME. Recent findings on genetics of systemic autoimmune diseases. Curr Opin Immunol 2010; 22(6): 698-705.

46. Li HM, Zhang TP, Leng RX, Li XP, Wang DG, Li XM, Ye $D Q$, Pan HF. Association of leptin and leptin receptor polymorphisms with systemic lupus erythematosus in a Chinese population. J Cell Mol Med 2017; 21(9): 17321741.

47. Sanchez-Margalet V, Martin-Romero C, Santos-Alvarez J, Goberna R, Najib S, Gonzalez-Yanes C. Role of leptin as an immunomodulator of blood mononuclear 
cells: mechanisms of action. Clin Exp Immunol 2003; 133(1): 11-19.

48. Otero M, Nogueiras R, Lago F, Dieguez C, Gomez-Reino JJ, Gualillo O. Chronic inflammation modulates ghrelin levels in humans and rats. Rheumatol (Oxford) 2004; 43(3): 306-310.

49. Boden G, Chen X, Kolaczynski JW, Polansky M. Effects of prolonged hyperinsulinemia on serum leptin in normal human subjects. J Clin Invest 1997; 100(5): 1107-1113.

50. Castracane VD, Kraemer RR, Franken MA, Kraemer GR, Gimpel T. Serum leptin concentration in women: effect of age, obesity, and estrogen administration. Fertil Steril 1998; 70(3): 472-477.

51. Gualillo O, Eiras S, Lago F, Diéguez C, Casanueva FF. Elevated serum leptin concentrations induced by experimental acute inflammation. Life Sci 2000; 67(20): 2433-2441.

52. van den Brink GR, O'Toole $T$, Hardwick $J \mathrm{CH}$, van den Boogaardt DE, Versteeg $H H$, van Deventer SJ, Peppelenbosch MP. Leptin Signaling in Human Peripheral Blood Mononuclear Cells, Activation of $p 38$ and p42/44 Mitogen-Activated Protein (MAP) Kinase and p70 S6 Kinase. Mol Cell Biol Res Commun 2000; 4(3): 144-150.

53. Samara A, Marie B, Pfister M, Visvikis-Siest S. Leptin expression in Peripheral Blood Mononuclear Cells (PBMCs) is related with blood pressure variability. Clin Chim Acta 2008; 395(1-2): 47-50.

54. Zarkesh-Esfahani $H$, Pockley G, Metcalfe RA, Bidlingmaier $M, W u$ Z, Ajami A, Weetman AP, Strasburger CJ, Ross RJ. High-dose leptin activates human leukocytes via receptor expression on monocytes. J Immunol 2001; 167(8): 4593-4599.

55. Dixit VD, Mielenz M, Taub DD, Parvizi N. Leptin induces growth hormone secretion from peripheral blood mononuclear cells via a protein kinase $C$ and nitric oxide dependent mechanism. Endocrinology 2003; 144(12): 5595-5603.

56. Matarese G, La Cava A, Sanna V, Lord GM, Lechler RI, Fontana S, Zappacosta S. Balancing susceptibility to infection and autoimmunity: a role for leptin? Trends in Immunology 2002; 23(4): 182-187. 